\title{
Antigens related to the major internal protein, p27, of a psoriasis associated retrovirus-like particle are expressed in patients with chronic arthritis
}

\author{
EYVIND RØDAHL AND OLE-JAN IVERSEN \\ From the Department of Microbiology, Faculty of Medicine, University of Trondheim, N-7000 Trondheim, \\ Norway
}

SUMMARY A rabbit antiserum against the major internal protein, p27, of a psoriasis associated retrovirus-like particle has been applied in an immunofluorescence assay for the detection of antigens cross reacting with p27 in patients with psoriatic arthritis, seronegative rheumatoid arthritis, or ankylosing spondylitis. Antigens reacting with anti-p27 antibodies were present in lymphocytes from blood or synovial fluid from all patients examined. However, the expression was restricted to $0 \cdot 01-0 \cdot 1 \%$ of the cells. Among the positive p27 cells were cells reacting with markers for T, B, or NK cells. The anti-p27 antibodies also reacted with mononuclear cells in the synovial membrane and with the internal wall of some small or medium sized vessels in sections of synovial biopsy specimens from the patients with chronic arthritis. The reaction with mononuclear synovial membrane cells was restricted to approximately $0 \cdot 1 \%$ of the cells. Blood lymphocytes or synovial sections from healthy persons did not react with the anti-p27 antibodies. The implication of these observations in the pathogenesis of chronic arthritis in man is discussed.

Key words: psoriatic arthritis, rheumatoid arthritis, ankylosing spondylitis, lymphocytes, synovial membrane, immunofluorescence assay.

Chronic inflammatory rheumatic disorders of man are a heterogenous group of disorders where the aetiology has remained obscure. In animals comparable conditions are sometimes observed as a consequence of retrovirus infections. ${ }^{12}$

Recently, we described the isolation of a retrovirus-like particle from a patient with psoriasis. ${ }^{3}$ The major internal protein, p27, of the particle is expressed by a subpopulation of epidermal cells both in the psoriatic lesion and in clinically uninvolved skin. ${ }^{4}$ p27 is also expressed by approximately $0 \cdot 1 \%$ of peripheral blood lymphocytes in patients with psoriasis. ${ }^{5}$

Psoriasis is complicated by arthritis in approximately $5 \%$ of all cases, ${ }^{6}$ the majority presenting with symptoms from peripheral joints. The prevalence of psoriasis among patients with seronegative rheumatoid arthritis (RA) is $9 \%$ compared with $1-2 \%$ in

Accepted for publication 24 April 1985.

Correspondence to Dr Eyvind Rødahl, Department of Microbiology, Faculty of Medicine. University of Trondheim, N-7000 Trondheim, Norway. population controls. ${ }^{7}$ Spinal involvement is observed in $20 \%$ of cases with psoriatic arthritis (PsoA) ${ }^{8}$ Among patients with ankylosing spondylitis (AS) the prevalence of psoriasis is $16 \% .{ }^{9}$ Psoriasis, PsoA, uncomplicated seronegative polyarthritis, and AS show an inter-related familial aggregation. ${ }^{8}$

This paper describes the presence of antigens cross reacting with $\mathrm{p} 27$ in sections of synovial biopsy specimens and in lymphocytes isolated from peripheral blood or synovial fluid from patients with PsoA, RA, or AS.

\section{Material and methods}

p27 ANTIGEN AND ANTI-p27 ANTIBODIES Purification of $p 27$

Retrovirus-like particles were isolated from the urine of a patient with extensive psoriasis by sucrose gradient ultracentrifugation. The major internal protein, p27, of the particles was purified by fractionation on a Con A Sepharose column (Pharmacia), immunosorbent chromatography, and gel 
filtration on a Sephacryl S-300 column (Pharmacia) in $6 \mathrm{M}$ guanidine hydrochloride (Sigma) as described previously. ${ }^{310}$ The antigen was purified to homogeneity as judged by sodium dodecyl sulphatepolyacrylamide gel electrophoresis (SDS-PAGE) of labelled antigen.

\section{Rabbit antiserum against p27}

A hyperimmune antiserum with specificity for $\mathrm{p} 27$ was obtained by immunising a rabbit with purified p27 isolated from four litres of urine..$^{5}$

CLINICAL SPECIMENS

Synovial biopsy specimens

Biopsy specimens were obtained from synovectomy specimens from two patients with RA, two patients with PsoA, and one patient with AS. Synovial biopsy specimens were also obtained from two otherwise healthy persons subjected to arthrotomy due to a mechanical disarrangement.

\section{Blood or synovial fluid}

Heparinised blood was obtained from five patients with RA, five with PsoA, and five with AS. Heparinised synovial fluid was obtained from two patients with RA, two with PsoA, and two with AS.

Heparinised blood was also collected from five healthy persons without known cases of chronic inflammatory disorders among their first degree relatives.

\section{FI, U ORESCENCE M I CROS COPY}

Preparation of blood or synovial fluid lymphocytes Lymphocytes were isolated by the one step sodium metrizoate/Ficoll procedure (Lymphoprep, Nyegaard \& Co.), and the cells were washed in phosphate-buffered saline $\mathrm{pH} 7 \cdot 2$ (PBS). The lymphocytes were adsorbed to coverslips that had been pretreated with $0 \cdot 1 \%$ poly-1-lysine (Sigma) and fixed in methanol.

\section{Preparation of sections from synovial biopsy} specimens

The biopsy specimens were fixed in $96 \%$ ethanol a $4^{\circ} \mathrm{C}$ for $18 \mathrm{~h}$, embedded in paraffin and routine्ठ $2-3 \mu \mathrm{m}$ sections prepared. The slides were incubate $\mathbb{P}$ at $56^{\circ} \mathrm{C}$ for $30 \mathrm{~min}$, deparaffinised in xylene $(2 \times$ §ึ $\mathrm{min}$ ), washed with absolute ethanol, and rehydrateक with decreasing concentrations of ethanol in saline $\overrightarrow{-}$

\section{Immunofluorescence assay}

Lymphocytes adsorbed to coverslips or sections of synovial biopsy specimens were incubated with anti p27 antiserum or preimmune serum diluted 1:60 in PBS at $37^{\circ} \mathrm{C}$ for $45 \mathrm{~min}$. The binding of rabbik antibodies was detected by fluorescein-conjugated swine antibodies to rabbit immunoglobuling (DAKO) $\left(20 \mathrm{~min}, 37^{\circ} \mathrm{C}\right)$.

Identification of lymphocyte subpopulations $\mathrm{T}$ cells, $\mathrm{T}_{\mathrm{h}}$ cells, $\mathrm{T}_{\mathrm{s}}$ cells, and $\mathrm{NK}$ cells wer⿸ identified by anti-leu 4 , anti-leu 3 , anti-leu 2 , an $\$$ anti-leu 11, respectively (Becton Dickinson mogo clonal antibodies). B cells were identified by B 0120 (Behringwerke AG, monoclonal antibodi Lymphocytes were isolated as described abo incubated with monoclonal antibodies in concentras tions recommended by the manufacturers at $20^{\circ} \widehat{\delta}$ for $45 \mathrm{~min}$, and washed with PBS. Texas Red conjugated antimouse immunoglobulins (Amersham 9 served as second antibodies. The cells were the $\vec{B}$ adsorbed to coverslips, fixed in methanol, an $\Phi$ labelled with anti-p27 antibodies and fluorescein? conjugated antirabbit immunoglobulins as describe above.
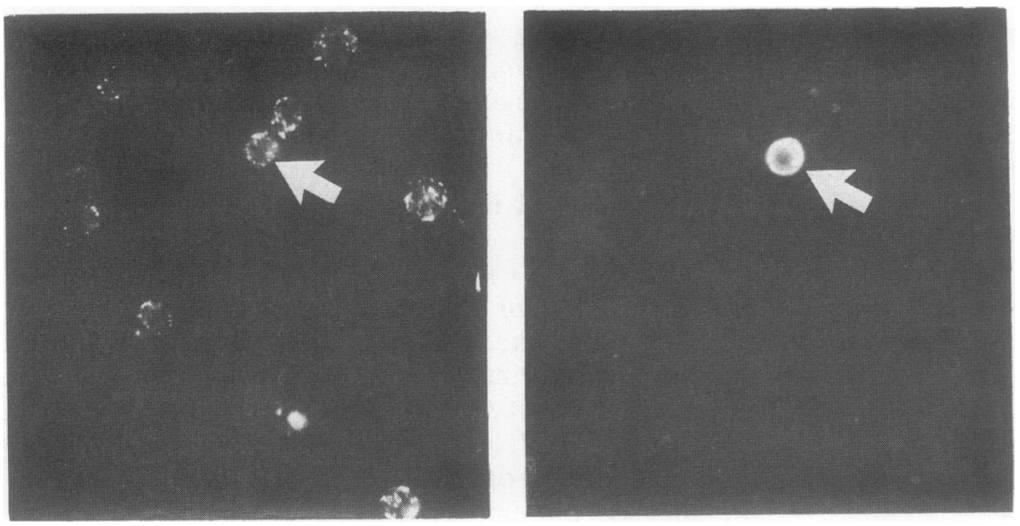

Fig. 1 Blood lymphocytes from patient with $A S$ isolated by the one step sodium metrizoate/Ficoll $\mathrm{N}$ procedure. The cells were doubly labelled with anti-leu 2 antibodies (left) and anti-p27 antibodies (right) as described above. The arrows indicate a 27 positive cell $(\times 400)$. 


\section{Results}

BLOOD AND SYNOVIAL FLUID LYMPHOCYTES After the incubation of blood lymphocytes from patients with RA, PsoA, or AS with anti-p27 antiserum followed by fluorescein-conjugated antirabbit immunoglobulins as second antibodies a bright cytoplasmatic fluorescence was observed in a minority of the cells (Fig. 1). The frequency of cells expressing antigens cross reacting with anti-p27 antibodies was $0 \cdot 01-0 \cdot 1 \%$ in all cases examined. Anti-p27 antibodies also reacted with synovial fluid lymphocytes (Fig. 2). No reaction was observed with preimmune serum (Fig. 3). Blood lymphocytes from healthy persons did not react with anti-p27 antibodies (frequency $<0.01 \%$ ).

For the identification of the lymphocytes reacting with anti-p27 antibodies a double labelling with monoclonal antibodies against various cell surface markers was performed. The lymphocytes were incubated with antibodies against markers for $T$ cells, B cells, or NK cells followed by Texas Red conjugated sheep antimouse immunoglobulins before fixation in methanol and subsequent incubation with anti-p27 antiserum and fluorescein-conjugated swine antirabbit immunoglobulins. Markers for either T, B, or NK cells were present on lymphocytes reacting with anti-p27 antibodies (Figs 1 and 2 ). The frequency of anti-p27 reactive cells was approximately the same for the three cell populations. Among the anti-p27 reactive T cells were cells with markers for $\mathrm{T}$ helper as well as $\mathrm{T}$ suppressor cells (Fig. 1)

SECTIONS OF SYNOVIAL BIOPSY SPECIMENS When sections of the synovial biopsy specimens from patients with RA, PsoA, or AS were incubated with anti-p27 antiserum followed by fluorescein-
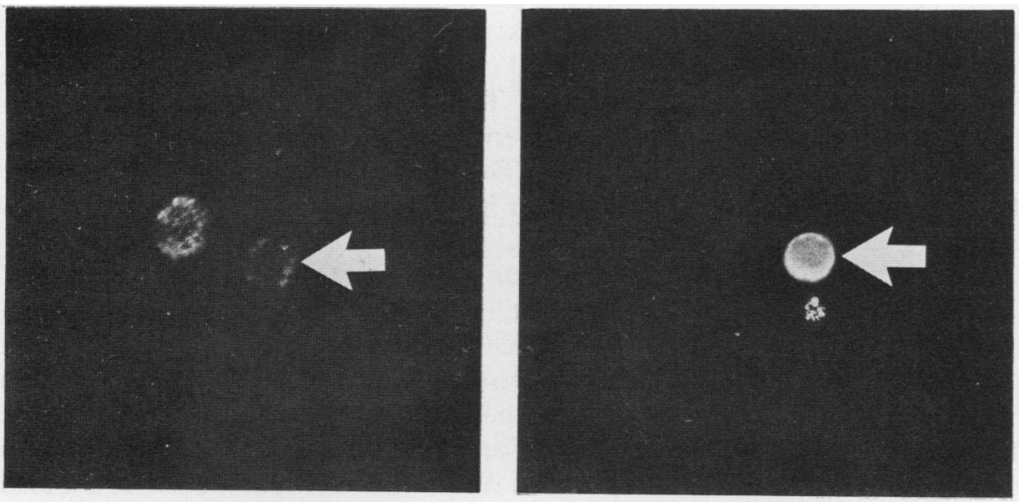

Fig. 2 Synovial fluid lymphocytes from a patient with $A S$ isolated by the one step sodium metrizoatel Ficoll procedure. The cells were doubly labelled with anti-leu 4 antibodies (left) and anti-p27 antibodies (right) as described above. The arrows indicate a p27 positive cell. $(\times 400)$.

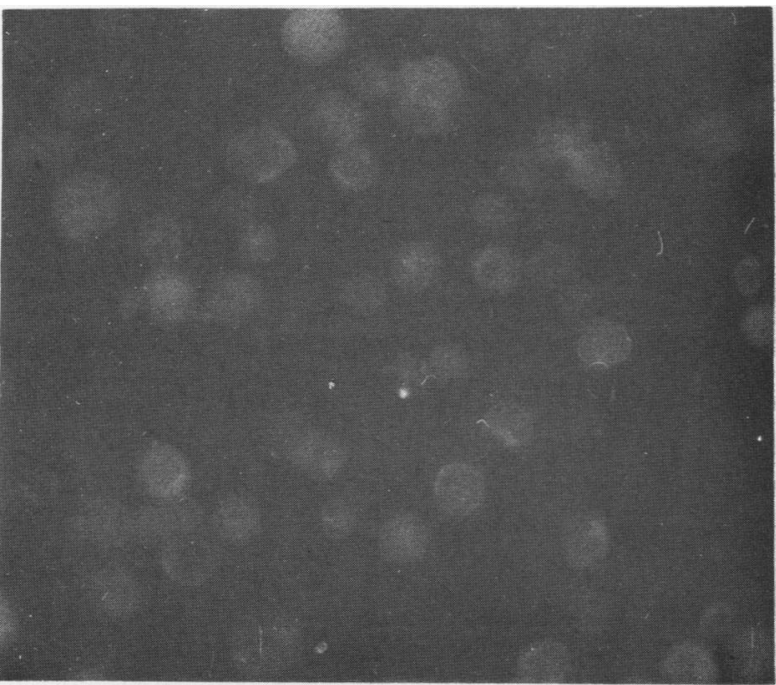

Fig. 3 Blood lymphocytes from a patient with AS isolated by the one step sodium metrizoate/Ficoll procedure. The cells were incubated with rabbit preimmune serum. $(\times 400)$. 


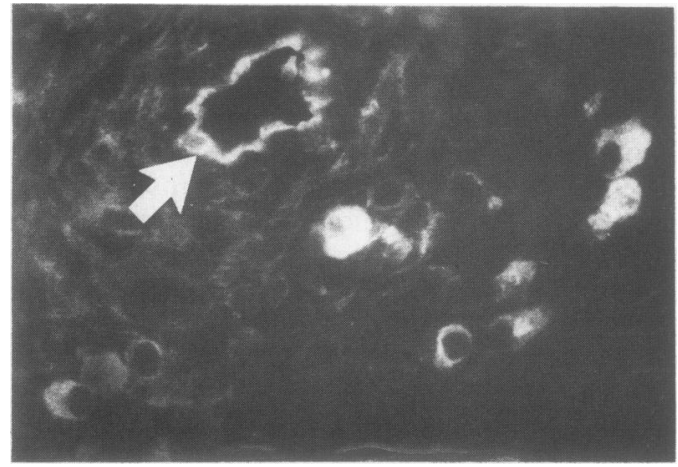

Fig. 4 Section of a synovial biopsy specimen from a patient with seronegative rheumatoid arthritis incubated with anti-p27 antiserum. The arrow indicates vascular fluorescence. Some mononuclear 127 positive cells appear scattered in the synovial tissue. $(\times 400)$.

conjugated antirabbit immunoglobulins a bright cytoplasmatic fluorescence was observed in approximately $0.1 \%$ of the cells. The reaction was quite similar in all of the biopsy specimens examined. The cells reacting with anti-p27 antibodies were mononuclear and appeared single or in small clusters scattered throughout the synovia (Fig. 4). A bright fluorescence was also observed on the internal surface of vessel walls (Fig. 4). The reaction was restricted to a minority of the vessels, but it was observed both in small and medium sized vessels. No reaction was observed with cells or vessel walls when preimmune serum was applied instead of antip27 antiserum. Synovial biopsy specimens from apparently healthy persons did not react with antip27 antiserum.

\section{Discussion}

In animals, retroviruses constitute a disease potential for the induction of several disorders either of chronic inflammatory or neoplastic character. ${ }^{11}$ Chronic inflammation is the hallmark of infections with the subfamily lentivirinae, ${ }^{11}$ which comprise the visna, maedi, and caprine arthritis encephalitis virus (CAEV). ${ }^{12}$

The pathology of the lesions observed after infection with CAEV is very similar to that observed in chronic polyarthritis in humans. ${ }^{13}$ This includes the presence of synovitis with a mononuclear cell infiltrate and hyperplasia of synovial lining cells. There are also skin changes (emaciation and exfoliation) and an increased susceptibility for the deposition of amyloid in various organs.

The isolation and characterisation of a retroviruslike particle from patients with psoriasis has been described previously. ${ }^{3}{ }^{10}$ The major internal pro tein, p27, of the particle is expressed in epiderma\$? cells in psoriatic lesions and in blood lymphocyte from patients with psoriasis. ${ }^{45}$ We have also showif the presence of p27 antigen and anti-p27 antibodie? in immune complexes from patients with PsoA.

In this study we have used anti-p27 antibodies as probe to examine specimens from patients wit\$ chronic arthritis for the presence of antigens cros» reacting with $\mathrm{p} 27$.

The anti-p27 antibodies reacted with lymphocytes. and synovial mononuclear cells from patients with PsoA, RA, and AS. The reaction was restricted to minority of cells, an observation also encountered is psoriasis. ${ }^{45}$ In infections with retroviruses a charact teristic feature is the restricted expression of virus. antigens. In visna expression of $\mathrm{p} 30$ is observed only in $0.03 \%$ of the cells. ${ }^{15} \mathrm{~A}$ frequency of the same order of magnitude was observed for cells reacting with anti-p27 antibodies in our patients with chronic arthritis. This low but persistent expression of antigen could provide the stimulus for chronie inflammation. The expression of viruses in lympho cytes is frequently observed in infections with the lentivirinae. ${ }^{16}$ The lymphotrophism of pathologic retroviruses in humans, the HTLV I, II, and IIIO well reported. ${ }^{17}$

The reaction of anti-p27 antiserum was restricted to cells, but in sections of synovial tissue bright fluorescence was observed on the internat wall of some vessels. Similar deposits have also beeid observed in the dermis of psoriatic lesions. ${ }^{4}$ The vascular reaction in psoriatic skin is probably due to the deposition of immune complexes but could als $\bar{\Phi}$ be explained by a local expression of antigen. ${ }^{4}{ }^{14}$ II 3 RA others have shown the presence of immunoglobulins, ${ }^{18}$ complement factors, ${ }^{18}$ and. virus-like particles ${ }^{19}$ in synovial vessel walls. These observations indicate that the reaction of anti-p2 $\frac{f}{6}$ antibodies with synovial vessel walls could be explained correspondingly to the reaction witlo psoriatic dermal vessels.

The properties of the psoriasis associated retrovirus-like particle have been described in detaiP elsewhere. ${ }^{310}$ Despite several attempts, we have not been able to show the presence of RNA dependent. DNA polymerase or high molecular weighs polyadenylated RNA in preparations containing purified particles from patients with psoriasis. 20 Thus there is no evidence for an infectious particle $\sigma$

Both complete and incomplete genomes of retros viruses are present as endogenous genetic elements in nearly all species, including humans. ${ }^{21} 22$ pathogenetic role of endogenous retrovirus antigens has been reported both in birds and in inbred strains of mice. ${ }^{23} 24$ Whether the psoriasis associated pare 
ticle is of endogenous or exogenous origin remains to be clarified. However, this topic and the possible association of the antigens cross reacting with antip27 antiserum in patients with RA or AS with a particle structure is currently being investigated in our laboratory.

This work was supported by grants from the Norwegian Society for Fight against Cancer. ER is a research fellow of the Norwegian Council for Science and the Humanities. The most generous help offered by $\operatorname{Dr} \varnothing$ Romberg, Dr E Støen, and Dr J Vassal in providing the clinical specimens is acknowledged. The technical assistance of Mrs Lillian Carlsson and Mrs Eli Johannessen is greatly appreciated.

\section{References}

1 Crawford T B, Adams D S, Cheevers W P, Cork L C. Chronic arthritis in goats caused by a retrovirus. Science 1980; 207: 997-9.

2 Pedersen N C, Pool R R, O’Brien T. Feline chronic progressive polyarthritis. Am J Vet Res 1980; 41: 522-35.

3 Iversen O-J. Isolation of virus like particles in urine from a psoriatic patient. Acta Pathol Microbiol Immunol Scand [B] 1983; 91: 407-12.

4 Iversen O-J, Rødahl E, Dalen A B. The major internal protein, p27, of a psoriasis associated retrovirus-like particle is expressed in psoriatic skin. Arch Virol (in press).

5 Iversen O-J, Dalen A B. The major internal protein, p27, of a retrovirus-like particle is expressed in blood lymphocytes from psoriatic patients. Arch Virol (in press).

6 Hellgren L. Association between rheumatoid arthritis and psoriasis in total populations. Acta Rheumatol Scand 1969; 15: 316-26.

7 Baker H. Epidemiological aspects of psoriasis and arthritis. $\mathrm{Br} \mathrm{J}$ Dermatol 1966; 78: 249-61.

8 Wright V. A unifying concept for the spondylarthropathies. Clin Orthop 1979; 143: 8-14.

9 Møller P, Vinje O, Kåss E, Berg K. The distribution of clinical findings in Bechterew's syndrome (ankylosing spondylitis) suggests distinct genetic subgroups. Clin Genet 1982; 22: 151-9.

10 Iversen O-J, Dalen A B. Urine proteins cross-reacting with antiserum against virus-like particles from cultured psoriatic epithelial cells. Acta Pathol Microbiol Immunol Scand /B] 1983; 91: 343-9.

11 Teich N, Wyke J, Mak T, Bernstein A, Hardy W. Pathogenesis of retrovirus-induced disease. In: Weiss R, Teich N, Varmus $H$.
Coffin J, eds. RNA tumor viruses. New York: Cold Spring Harbor Laboratory, 1982: 785-998.

12 Teich $\mathbf{N}$. Taxonomy of retroviruses. In: Weiss $\mathbf{R}$, Teich $\mathbf{N}$, Varmus $\mathrm{H}$, Coffin J, eds. RNA tumor viruses. New York: Cold Spring Harbor Laboratory, 1982: 25-207.

13 Adams D S, Crawford T B, Klevjer-Anderson P. A pathogenetic study of the carly connective tissue lesions of viral caprine arthritis-encephalitis. Am J Pathol 1980; 99: 257-78.

14 Iversen O-J, Rødahl E. The major internal protein, p27, of a retrovirus-like particle participates in immune complex formation in psoriasis. Arch Virol (in press).

15 Haase A T, Stowring L, Narayan O, Griffin D, Price D. Slow persistent infection caused by visna virus: role of host restriction. Science 1977; 195: 175-7.

16 Pétursson G, Nathanson N, Georgsson G, Panitch H, Pálsson P A. Pathogenesis of visna. I. Sequential virologic, serologic and pathologic studies. Lab Invest 1976; 35: 402-12.

17 Popovic M, Sarngadharan M G, Read E, Gallo R C. Detection, isolation, and continuous production of cytopathic retroviruses (HTLV III) from patients with AIDS and pre-AIDS. Science 1984; 224: 497-500.

18 Nowoslawski A. Immunopathological features of rheumatoid arthritis. In: Müller W, Harwerth H-G, Fehr K, eds. Rheumatoid arthritis. Pathogenetic mechanisms and consequences in therapeutics. London and New York: Academic Press, 1971: 325-35.

19 Schumacher H R. Synovial membrane and fluid morphologic alterations in early rheumatoid arthritis: microvascular injury and virus-like particles. Ann NY Acad Sci 1975; 256: 39-64.

20 Iversen O-J, Nissen-Meyer J, Dalen A B. Characterization of virus-like particles from a psoriatic patient with respect to the possible presence of particle-associated RNA and RNAdirected DNA polymerase. Acta Pathol Microbiol Immunol Scand [B] 1983; 91: 413-7.

21 Coffin J. Endogenous viruses. In: Weiss R, Teich N, Varmus $\mathrm{H}$, Coffin J, eds. RNA tumor viruses. New York: Cold Spring Harbor Laboratory, 1982: 1109-203.

22 Rabson A B, Steele P E, Garon C F, Martin M A. mRNA transcripts related to full-length endogenous retroviral DNA in human cells. Nature 1983; 306: 604-7.

23 Weiss R A, Frisby D P. Are avian endogenous viruses pathogenic? In: Yohn D S, Blakeslee J R, eds. Advances in comparative leukemia research 1981. Amsterdam: Elsevier, 1982: 303-11.

24 Izui S, Hara I, Le Ming Hang, Elder J H, McConahey P J, Dixon F J. Association of elevated serum glycoprotein gp70 immune complex formation and accelerated lupus nephritis in autoimmune male BXSB mice. Clin Exp Immunol 1984; 56: 272-80. 